Filol. Linguíst. Port., São Paulo, v. 17, n. 2, p. 641-673, jul./dez. 2015

http://dx.doi.org/10.11606/issn.2176-9419.v17i2p641-673

\title{
Relaçóes de discurso em narrativas jornalísticas: em busca de sistematizações
}

\author{
Discourse relations in journalistic narratives: searching for \\ systematizations
}

Gustavo Ximenes Cunha ${ }^{1}$

Universidade Federal de Minas Gerais, Belo Horizonte, Minas Gerais, Brasil

\begin{abstract}
Resumo: Na narrativa jornalística, o jornalista realiza diferentes manobras discursivas, tais como comentar, reformular, contra-argumentar, exemplificar etc. Com base no Modelo de Análise Modular do Discurso, este trabalho mostra que, por serem constitutivas do modo como o jornalista narra, essas manobras não podem ser concebidas como desvinculadas da situação em que são realizadas. Assim, a análise de um corpus formado por 53 sequências narrativas extraídas de reportagens permitiu observar uma série de regularidades, como o predomínio de relaçóes argumentativas e comentativas, que se deve a propriedades do gênero reportagem.
\end{abstract}

Palavras-chave: Relaçóes de discurso. Sequências narrativas. Reportagens.

\begin{abstract}
On narrative journalism, journalists perform different discursive actions, such as commenting, opposing, exemplifying etc. Based on the Modular Approach of Discourse Analysis, this work proposes that these actions are constitutive of how the journalist narrates and cannot be studied as if they were detached from the context. Thus, the analysis of 53 narrative sequences allowed us to observe regularities, such as the predominance of argumentative relations, regularities that are connected to the genre.
\end{abstract}

Keywords: Discourse relations. Narrative sequences. Reports

1 Professor adjunto da Faculdade de Letras (FALE) da Universidade Federal de Minas Gerais (UFMG), Belo Horizonte, Minas Gerais, Brasil, e-mail: ximenescunha@yahoo.com.br. 


\section{INTRODUÇÃO}

Este trabalho constitui um recorte de uma pesquisa mais ampla (Cunha, 2013), em que investiguei o impacto da dimensão situacional do discurso sobre a constituição dos tipos de discurso. Especificamente, a pesquisa procurou mostrar que os tipos de discurso (narração, descrição, argumentação) são noçôes profundamente atreladas à noção de gênero do discurso, e que, por isso mesmo, não é possível conceber os tipos como desvinculados dos gêneros de cuja construçáo composicional participam ${ }^{2}$. Em suma, focalizando o gênero reportagem, evidenciei que este possui um tipo narrativo próprio que, por impacto das características do gênero, se distingue dos tipos narrativos de outros gêneros, como a fábula, o relato de experiência pessoal ou a entrevista de emprego (cf. Cunha, 2013, 2015).

No presente estudo, restrinjo o campo de visão para, de modo aprofundado, evidenciar que a dimensão situacional do discurso, identificada neste trabalho particularmente com a noçáo de gênero do discurso ${ }^{3}$, impacta a forma como as informaçóes são articuladas no interior das sequências discursivas. Tendo como objeto de análise o tipo narrativo do gênero reportagem, procuro revelar que, na composiçáo de uma sequência narrativa, o jornalista realiza diferentes manobras discursivas, tais como comentar acontecimentos, situá-los temporalmente uns em relação aos outros, reformular informaçóes dadas, contra-argumentar declaraçóes dadas por figuras, por exemplo, do mundo político, exemplificar conceitos ou dados apresentados por especialistas etc. Considero que, por serem constitutivas do modo como o jornalista narra, essas manobras não podem ser concebidas como desvinculadas da situação em que são realizadas. Ou seja, o plano da organização discursiva referente às relaçôes de discurso é profundamente impactado pelo gênero do discurso.

Para revelar em que medida o gênero do discurso tem influência sobre a maneira como os jornalistas, ao narrarem em reportagens, fazem a articulação das

2 Para grande parte da literatura atual sobre gêneros do discurso, os tipos seriam transversais em relaçáo aos gêneros, numa postura semelhante à de Bronckart (2007, p. 75): "Enquanto, devido a sua relação de interdependência com as atividades humanas, os gêneros são múltiplos, e até mesmo em número infinito, os segmentos que entram em sua composição (segmentos de relato, de argumentação, de diálogo, etc.) são em número finito, podendo, ao menos parcialmente, ser identificados por suas características linguísticas específicas".

3 Neste artigo, cada gênero (reportagem, aula, bula de remédio, ata de condomínio, bate-papo etc.) é entendido como um conjunto de representaçóes sócio-historicamente adquiridas que os membros de uma coletividade ativam para participar das atividades sociais (Cunha, 2013).

Cunha, G.X. Relações de discurso em narrativas jornalísticas... 
informaçóes mobilizadas, apresento inicialmente a abordagem teórica com cujos instrumentos o estudo foi desenvolvido, que é o Modelo de Análise Modular do Discurso. Nessa apresentação, em virtude dos objetivos deste trabalho, não procedo a uma descriçáo minuciosa do modelo modular. Vou me concentrar na exposição do modo como essa abordagem estuda a forma de organização relacional do discurso.

Em seguida, exponho os resultados das análises, descrevendo, de forma detalhada, as relaçóes de discurso (comentário, argumento, contra-argumento, tempo, reformulaçáo etc.) que se estabelecem em um corpus formado por 53 sequências narrativas extraídas de dezesseis reportagens de edições de janeiro de 2010 das revistas Carta Capital, Época, IstoÉ e Veja. Com base nessa descrição, será possível evidenciar o papel que tais relaçóes exercem na construção das sequências narrativas das reportagens estudadas, bem como de que maneira são influenciadas pelo gênero reportagem.

\section{A FORMA DE ORGANIZAÇÃO RELACIONAL DO DISCURSO}

Desenvolvido na Universidade de Genebra por Eddy Roulet e equipe, o Modelo de Análise Modular do Discurso constitui um instrumento de descrição e explicação da complexidade discursiva. Em sua versão atual (Roulet et al., 2001; Marinho, 2004; Marinho et al., 2007; Cunha, 2014), o modelo compóe um quadro teórico e metodológico que visa a reunir, em uma mesma abordagem da complexidade da organização do discurso, as contribuiçôes de pesquisadores que se centraram em aspectos isolados dessa organização.

Essa postura integradora do modelo se manifesta em sua capacidade de propor o diálogo entre pesquisas desenvolvidas no interior de diferentes disciplinas: Linguística (Bakhtin, Ducrot, Kerbrat-Orecchioni), Sociologia (Goffman, Schegloff), Filosofia (Habermas, Ricoeur), Psicologia (Vygotsky, Bronckart) (Roulet et al., 2001). O esforço pela criação de um modelo, ao mesmo tempo, tão amplo e preciso justifica-se pela constatação de que

a construção e a interpretação do discurso são submetidas a três tipos de restriçóes: restriçóes que podemos chamar situacionais, ligadas ao universo de referência e à situação de interação; restriçóes linguísticas, ligadas à sintaxe e ao léxico da (ou das) variedade(s) de língua(s) utilizada(s), e restriçóes textuais, ligadas à estrutura hierárquica do texto (Roulet et al., 2001, p. 44). 
Por essas razóes, o modelo modular constitui um instrumento de análise que permite integrar e articular, em uma perspectiva cognitivo-interacionista, as dimensóes linguística, textual e situacional da organização do discurso. Conforme a metodologia adotada, identificam-se, inicialmente, os módulos que entram na composição do discurso. Nessa abordagem, cada dimensão do discurso se constitui de módulos. Assim, a dimensão linguística se constitui dos módulos lexical e sintático; a textual é composta pelo hierárquico; e a situacional se configura a partir dos módulos interacional e referencial. Posteriormente, procura-se mostrar como as informaçôes resultantes do estudo dos módulos se combinam em formas de organização do discurso. No modelo modular, distinguem-se dois tipos de formas de organização: as elementares e as complexas. As formas de organização elementares (fono-prosódica, semântica, relacional, informacional, enunciativa, sequencial e operacional) resultam da combinação ou acoplagem de informaçóes extraídas dos módulos. Já as complexas (periódica, tópica, polifônica, composicional e estratégica) são resultantes da combinação ou acoplagem de informaçôes extraídas dos módulos e das formas de organização elementares e/ou complexas (cf. Roulet et al., 2001; Marinho, 2004; Cunha, 2014).

No modelo, o estudo das manobras discursivas realizadas por meio da articulação dos constituintes textuais se faz na forma de organização relacional. Nela, são centrais as informaçóes do módulo hierárquico, em que se considera que "toda intervenção linguageira (cumprimento, pedido, asserção etc.) constitui uma PROPOSIÇÃO, que desencadeia um processo de negociação entre os interactantes" (Roulet et al., 2001, p. 57). Assim, um diálogo formado por uma pergunta (Que horas são?), por uma resposta (São nove horas.) e por um agradecimento (Obrigado.) evidencia um processo em que uma proposição (a pergunta) desencadeia uma reação (a resposta), que motiva uma ratificação (o agradecimento).

Entretanto, nas interaçóes efetivamente realizadas, as fases desse processo de negociação (proposição, reação, ratificação) assumem configuraçóes complexas, raramente se reduzindo à intervenção de um único ato. Na interação mediada por discurso oral, a pergunta de um entrevistador, por exemplo, pode levar o entrevistado a responder por um turno complexo formado por vários atos. Por isso, a negociação conjunta dos interactantes costuma levar à construção de unidades discursivas complexas. Assim, a toda unidade textual subjaz um processo de negociação complexo e altamente dinâmico.

No módulo hierárquico, a reconstrução desse processo é feita pelo analista por meio das estruturas hierárquicas. Essas são formadas pelos três tipos de constituintes que os interactantes produzem em toda interação verbal: trocas, intervençôes e atos. 
- Troca: unidade textual máxima; formada por intervençóes que refletem as várias proposiçôes, reaçôes e ratificações de uma negociação.

- Intervenção: unidade constitutiva da troca; pode ser formada por apenas um ato, mas costuma apresentar uma configuração complexa, da qual participam outras intervençóes, atos e até mesmo trocas.

- Ato: unidade textual mínima; constitui a menor unidade delimitada por uma e outra passagem da memória discursiva, a qual é compreendida como o "conjunto de saberes conscientemente partilhados pelos interlocutores" (Berrendonner, 1983, p. 230).

Com a estrutura hierárquica, estudam-se as hierarquias e as relaçóes que os constituintes do texto - trocas, intervençôes e atos - estabelecem entre si. Essas relaçôes são de três tipos: dependência, interdependência e independência. Existe uma relação de dependência entre dois constituintes, quando a presença de um deles depende da presença do outro. $\mathrm{O}$ constituinte dependente é chamado de subordinado, ao passo que o outro é denominado principal. A relação de interdependência se dá quando um não pode existir sem o outro, como ocorre numa troca formada por pergunta e resposta. Finalmente, há uma relação de independência quando a presença de um constituinte não depende da presença de outro. Nesse tipo, as intervenções ou os atos são coordenados.

Combinando informaçóes do módulo hierárquico com informaçóes dos módulos lexical, sintático e referencial, o estudo da forma de organização relacional tem como um de seus objetivos principais identificar as relações interativas genéricas entre os constituintes da estrutura hierárquica e informaçóes da memória discursiva.

Tal identificação se baseia em uma lista reduzida de oito categorias: argumento, contra-argumento, reformulação, topicalização, tempo, preparação, comentário e clarificação ${ }^{4}$. O estabelecimento dessas categorias se justifica pelo fato de que o produtor do discurso, na tentativa de alcançar seus objetivos comunicativos no desenvolvimento do processo de negociação, pode elaborar intervençóes complexas. Nessas intervençóes, ele pode introduzir argumentos para reforçar um ponto de vista, rejeitar uma ideia com a apresentaçáo de contra-argumentos, comentar partes de seu texto, reformular ideias, tornando-as mais claras para seu ouvinte/leitor, enumerar os sucessivos eventos de uma narração etc. (Roulet, 2006; Cunha, 2012).

4 A explicação detalhada de cada categoria será realizada a seguir, ao longo da discussão dos resultados da pesquisa. 
As categorias de relaçóes genéricas podem ser explicitadas por marcadores linguísticos, como os conectores. No modelo modular, são as marcas linguísticas pertencentes a diferentes classes gramaticais (conjunções, advérbios, pronomes relativos etc.) que dão indicaçóes acerca da relação interativa verificável entre um contituinte textual e informaçóes previamente estocadas na memória discursiva. Nesse sentido, "são marcas que servem para especificar uma relação interativa via mecanismos inferenciais" (Rossari, 1999, p. 181), dando indicaçóes ainda sobre o estatuto principal ou subordinado do constituinte que introduz. Como exemplo, a relaçáo interativa de contra-argumento pode ser marcada por conectores, como mas, que introduz constituinte principal, e embora, que introduz constituinte subordinado.

$\mathrm{Na}$ continuação deste trabalho, apresento os resultados do estudo que investigou o impacto do gênero reportagem sobre a forma de organização relacional de sequências narrativas encontradas.

\section{A FORMA DE ORGANIZAÇÁO RELACIONAL DA NARRATIVA JORNALÍSTICA}

Como informado na introdução do presente artigo, este item se dedica à apresentação da análise da forma de organização relacional de um corpus formado por 53 sequências narrativas, extraídas de dezesseis reportagens veiculadas em janeiro de 2010, nas revistas semanais de informação Carta Capital, Época, IstoÉ e $V_{e j a}{ }^{5}$. A análise foi realizada com o objetivo de identificar e explicar regularidades ou tendências no modo como os jornalistas, ao produzirem um discurso pertencente ao gênero reportagem, articulam os constituintes textuais das sequências narrativas.

Assim, exponho, inicialmente, os resultados quantitativos da análise, parte basicamente descritiva. Depois, procedo a uma discussão ou explicação desses resultados, focalizando cada uma das categorias genéricas de relaçóes interativas identificadas no estudo.

5 Essa análise revisa e aprofunda parte do estudo apresentado em Cunha (2013, cap. 6). 


\subsection{RESULTADOS QUANTITATIVOS DA ANÁLISE RELACIONAL DA NARRATIVA JORNALÍSTICA}

Como o gênero do discurso constitui uma forma de agir socialmente estabilizada no interior das esferas de uso da língua, considerei como forte a hipótese de que o gênero reportagem tem impacto sobre a forma como, ao narrar, o jornalista articula os constituintes textuais, o que pode levar à manifestação de recorrências nessa articulação. Dessa forma, feita a análise relacional das 53 sequências, busquei essas recorrências de um ponto de vista quantitativo. A análise se desenvolveu em quatro etapas: (i) contagem de todas as relaçóes de discurso identificadas no corpus; (ii) contagem de todos os marcadores (conectores e estruturas sintáticas) das relaçóes identificadas; (iii) verificaçáo da funçáo relacional (argumento, reformulação, comentário etc.) que costuma exercer cada episódio da sequência narrativa (estágio inicial, complicação, resolução etc.); (iv) contagem das relaçôes de discurso que se estabelecem no interior de cada episódio. A seguir, exponho os resultados de cada etapa.

Inicio pela verificação do total de relaçôes pertencentes a cada categoria genérica. A Tabela 1 traz os resultados dessa contagem.

Tabela 1 - Frequência das categorias de relaçóes de discurso e coordenaçáo

\begin{tabular}{|l|c|c|}
\hline $\begin{array}{c}\text { Categorias de relaçóes de discurso } \\
\text { e coordenaçáo }\end{array}$ & No $^{\circ}$ & $\%$ \\
\hline Argumento & 127 & 28,30 \\
\hline Comentário & 108 & 24,05 \\
\hline Topicalizaçáo & 66 & 14,70 \\
\hline Tempo & 61 & 13,58 \\
\hline Contra-argumento & 35 & 7,80 \\
\hline Preparaçáo & 26 & 5,79 \\
\hline Reformulaçáo & 13 & 2,89 \\
\hline Coordenaçáo & 13 & 2,89 \\
\hline Total & 449 & 100 \\
\hline
\end{tabular}

Das categorias genéricas de relações propostas pelo modelo modular, apenas a de clarificação não foi identificada no corpus, já que as relações que abrange ligam um constituinte principal a uma troca aberta por uma questão. As sequências 
narrativas das reportagens estudadas se compóem exclusivamente de intervençôes, não apresentando em sua estrutura trocas entre interlocutores/personagens.

$\mathrm{Na}$ tabela, o fato que mais chama atenção é a predominância de relações de argumento e de comentário nas sequências narrativas de reportagens. Somadas, correspondem a mais da metade (52,35\%). Contrariando a expectativa de que, num corpus formado por narrativas, seriam mais frequentes as relaçóes temporais, esse resultado revela a dimensão fortemente argumentativa das reportagens de revistas semanais de informação, em que mesmo a narrativa é marcada pela busca do jornalista por levar o leitor a modificar ou reforçar determinadas crenças e modos de pensar.

Em seguida, como exposto, a análise procurou identificar os marcadores das relaçóes identificadas, a fim de verificar a frequência com que os jornalistas, ao produzirem sequências narrativas, marcam as relações de discurso. Como marcadores de relaçóes este trabalho considera apenas os conectores e, para a categoria de topicalização, constituintes textuais que ocorrem na margem esquerda de outros constituintes. A Tabela 2 apresenta todos os marcadores identificados, bem como o número (entre parênteses) de ocorrências de cada marcador.

\section{Tabela 2 - Frequência das marcas das categorias de relaçóes de discurso e da coordenação}

\begin{tabular}{|c|c|c|}
\hline Categorias & Marcas & Totais \\
\hline Argumento & 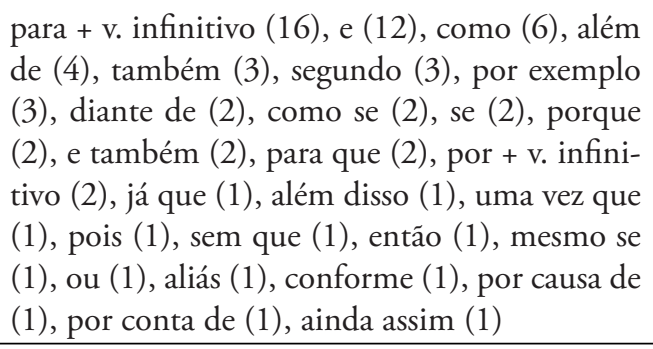 & $\begin{array}{c}74 \\
(34,26 \%)\end{array}$ \\
\hline Topicalização & deslocamento à esquerda & $\begin{array}{c}62 \\
(28,70 \%) \\
\end{array}$ \\
\hline Tempo & $\begin{array}{l}\text { e (11), quando (6), desde (3), após (3), antes } \\
\text { de (3), depois de (2), enquanto ( } 2) \text {, a partir de } \\
\text { (1), depois (1), e depois (1), à medida que (1), } \\
\text { até que (1) }\end{array}$ & $\begin{array}{c}35 \\
(16,20 \%)\end{array}$ \\
\hline Comentário & $\begin{array}{l}\text { que (11), e (4), onde ( } 4) \text {, cujo (1), o que (1), } \\
\text { no qual (1) }\end{array}$ & $\begin{array}{c}23 \\
(10,65 \%)\end{array}$ \\
\hline
\end{tabular}




\begin{tabular}{|l|l|c|}
\hline Contra-argumento & $\begin{array}{l}\text { mas (12), só que (1), mas mesmo assim (1), } \\
\text { apesar de (1), no entanto (1), apesar disso (1), } \\
\text { porém (1), porém (1), em vez de (1), e (1) }\end{array}$ & $\begin{array}{c}20 \\
(9,26 \%)\end{array}$ \\
\hline Coordenaçáo & e (2) & $2(0,93 \%)$ \\
\hline Reformulaçáo & - & 0 \\
\hline Preparaçáo & - & 0 \\
\hline Total & & $\begin{array}{c}216 \\
(100 \%)\end{array}$ \\
\hline
\end{tabular}

Como evidencia a Tabela 2, algumas categorias genéricas de relações não apresentaram qualquer marcador nas sequências componentes do corpus, como as de reformulação e preparação. Isso não significa, porém, que tais marcas não ocorram em outros tipos de sequências componentes das reportagens estudadas nesta pesquisa. Isto é, se dáo nas sequências que pertencem aos outros tipos propostos pelo modelo modular (descritivo e deliberativo) ${ }^{6}$.

Outra informação relevante sobre o corpus apresentada no quadro é a polifuncionalidade do conector $e$, a qual se manifesta na presença desse conector na maior parte das categorias ${ }^{7}$. De fato, nas sequências narrativas de reportagens, tal conector apresenta diferentes valores (argumento, contra-argumento, comentário, tempo) e atua ainda na junção de constituintes coordenados, entre os quais não é possível inferir uma relação de discurso. Esse último tipo de emprego do $e$ justifica a linha coordenação do quadro.

$\mathrm{O}$ quadro evidencia ainda que, nas sequências narrativas de reportagens, a categoria cujas relaçôes são marcadas por uma maior variedade de expressôes conectivas é a de argumento, que apresenta 27 tipos diferentes de conectores. Entretanto não é essa a que apresentou maior porcentagem de relaçôes marcadas por conectores ou construçóes sintáticas, como mostra a Tabela 3:

6 É o que mostra este trecho: "Outro aparelho, o Piezômetro, mede o nível de água nos solos das montanhas para mostrar quando eles começam a liquidificar, ou seja, quando o solo começa a virar lama”. Pertencente a uma sequência descritiva, o trecho traz a expressão conectiva ou seja, que é marca típica da relação de reformulação.

7 Em estudo sobre o português falado, Camacho (1999) observa que o $e$, quando juntor de oraçóes, ganha especialmente os valores semânticos de adição, adversidade e conclusão. Em Camacho (2001), aponta-se ainda o papel discursivo do $e$ na introdução de oraçóes modalizadoras e de comentários. 
Tabela 3 - Frequência de relaçóes marcadas

\begin{tabular}{|l|c|c|}
\hline \multicolumn{1}{|c|}{ Categorias } & Número de relaçóes marcadas & $\begin{array}{c}\text { Total de relaçóes } \\
(\mathbf{1 0 0 \% )}\end{array}$ \\
\hline Argumento & $74(58,26 \%)$ & 127 \\
\hline Comentário & $23(21,29 \%)$ & 108 \\
\hline Topicalizaçáo & $62(93,93)$ & 66 \\
\hline Tempo & $35(57,37 \%)$ & 61 \\
\hline Contra-arg. & $20(57,14 \%)$ & 35 \\
\hline Preparaçáo & 0 & 26 \\
\hline Reformulaçáa & 0 & 13 \\
\hline Coordenaçáo & $2(15,38 \%)$ & 13 \\
\hline
\end{tabular}

Do ponto de vista percentual, a topicalização foi a que apresentou maior quantidade de relaçóes marcadas, já que, em 62 (93,93\%) das 66 relações dessa categoria, a relação é marcada/explicitada pelo recurso do deslocamento de um constituinte à esquerda.

Estudadas a frequência das relaçóes de discurso e sua marcação no corpus completo, a análise descritiva buscou, nas duas etapas seguintes, aproximar os resultados do estudo da forma de organização relacional, sobre a articulação textual, com o estudo da estrutura das sequências narrativas, estudo que, no modelo modular, se faz em outra forma de organização, a sequencial. Em linhas gerais, essa forma de organização define os tipos de discurso (narração, descrição e deliberação) e segmenta os discursos nas sequências em que os tipos se manifestam (Roulet et al., 2001). Em Cunha (2013), o estudo de um corpus formado por 127 sequências narrativas, do qual fazem parte as 53 sequências estudadas neste trabalho, permitiu constatar que elas manifestam um tipo narrativo que se compóe destes episódios: sumário, estágio inicial, complicação, avaliação, resolução e estágio final ${ }^{8}$.

Nessa aproximação das formas de organização relacional e sequencial, o primeiro passo consistiu em identificar as relaçóes de discurso que são estabelecidas entre os episódios, a fim de investigar a função (argumentativa, temporal, contra-argumentativa, reformulativa etc.) que cada episódio costuma exercer na

8 Para caracterização detalhada de cada um desses episódios, cf. Cunha (2013, cap. 5, 2015). Exemplos de sequências narrativas que atualizam esse tipo narrativo bem como explicaçôes pontuais sobre os episódios serão dados adiante, ao longo das análises. 
macroestrutura das sequências. Esse estudo se mostrou pertinente, pois, durante a análise da forma de organização relacional das sequências, percebi que alguns episódios costumam ocorrer em constituintes subordinados e exercem de forma recorrente uma mesma função, como a de preparação, enquanto outros costumam acontecer em constituintes principais e, por isso, são alvo de preparaçóes, argumentaçóes, comentários feitos em outros constituintes das sequências. A Tabela 4 traz os resultados correspondentes. A letra P, na primeira coluna, indica as ocorrências dos episódios que ocorrem em constituintes principais.

\section{Tabela 4 - Frequência das funçóes dos episódios do tipo narrativo da reportagem}

\begin{tabular}{|c|c|c|c|c|c|c|c|c|c|c|c|c|}
\hline & \multicolumn{2}{|c|}{ Complicaçáo } & \multicolumn{2}{|c|}{ Avaliação } & \multicolumn{2}{|c|}{$\begin{array}{c}\text { Estágio } \\
\text { inicial }\end{array}$} & \multicolumn{2}{|c|}{ Resolução } & \multicolumn{2}{|c|}{ Sumário } & \multicolumn{2}{|c|}{ Estágio final } \\
\hline & $\mathbf{N}$ & $\%$ & $\mathbf{N}$ & $\%$ & $\mathbf{N}$ & $\%$ & $\mathbf{N}$ & $\%$ & $\mathbf{N}$ & $\%$ & $\mathbf{N}$ & $\%$ \\
\hline arg. & 7 & 13,20 & 7 & 16,30 & 3 & 7,80 & 1 & 3,03 & 0 & 0 & 0 & 0 \\
\hline com. & 4 & 7,55 & 29 & 67,44 & 2 & 5,27 & 2 & 6,06 & 0 & 0 & 1 & 8,33 \\
\hline c-a. & 0 & 0 & 3 & 6,97 & 0 & 0 & 2 & 6,06 & 0 & 0 & 3 & 25,00 \\
\hline prep. & 0 & 0 & 1 & 2,32 & 5 & 13,15 & 0 & 0 & 17 & 77,27 & 0 & 0 \\
\hline tem. & 8 & 15,09 & 1 & 2,32 & 7 & 18,42 & 1 & 3,03 & 0 & 0 & 1 & 8,33 \\
\hline top. & 0 & 0 & 0 & 0 & 11 & 28,95 & 0 & 0 & 0 & 0 & 0 & 0 \\
\hline ref. & 0 & 0 & 0 & 0 & 0 & 0 & 1 & 3,03 & 0 & 0 & 0 & 0 \\
\hline $\mathbf{P}$ & 34 & 64,16 & 2 & 4,65 & 10 & 26,31 & 26 & 78,79 & 5 & 22,73 & 7 & 58,34 \\
\hline Total & 53 & 100 & 43 & 100 & 38 & 100 & 33 & 100 & 22 & 100 & 12 & 100 \\
\hline
\end{tabular}

Esses resultados são importantes porque revelam tendências na forma como os jornalistas constróem as sequências narrativas de reportagens. Em tais sequências, o sumário costuma exercer a função de preparação (77,27\%). Já a avaliação exerce predominantemente a função de comentário (67,44\%). A complicação, por sua vez, costuma ser principal em relação a outros episódios $(64,16 \%)$. Isso significa que raramente uma complicação vai funcionar como comentário, marco temporal ou argumento para a informação ativada em outro constituinte textual. Essa característica da complicação se explica, em grande medida, por sua natureza referencial. Ela costuma ser o episódio central da sequência narrativa ou aquele que contém as informaçōes mais importantes que o jornalista quer fazer o leitor saber, justificando a própria ação do jornalista de produzir uma sequência desse tipo (Cunha, 2013, 2015). Nesse sentido, são informaçóes trazidas em 
outros constituintes que, articulando-se à complicação, vão comentá-la, situá-la temporalmente, definir qual seu tópico, prepará-la etc.

Por fim, o segundo passo da aproximação entre as formas de organização sequencial e relacional consistiu na verificação da frequência das categorias de relações de discurso no interior de cada episódio das sequências narrativas. Tal estudo permitiu chegar aos resultados apresentados na seguinte Tabela.

\section{Tabela 5 - Frequência das categorias de relaçóes de discurso e coordenaçáo em cada episódio}

\begin{tabular}{|l|c|c|c|c|c|c|c|c|c|c|c|c|}
\hline & \multicolumn{3}{|c|}{ Complicaçáo } & \multicolumn{2}{|c|}{ Avaliaçáo } & \multicolumn{2}{|c|}{$\begin{array}{c}\text { Estágio } \\
\text { inicial }\end{array}$} & \multicolumn{2}{c|}{ Resoluçáo } & \multicolumn{2}{c|}{ Sumário } & \multicolumn{2}{|c|}{$\begin{array}{c}\text { Estágio } \\
\text { final }\end{array}$} \\
\cline { 2 - 16 } & $\mathbf{N}$ & $\%$ & $\mathbf{N}$ & $\%$ & $\mathbf{N}$ & $\%$ & $\mathbf{N}$ & $\%$ & $\mathbf{N}$ & $\%$ & $\mathbf{N}$ & $\%$ \\
\hline arg. & 31 & 27,93 & 34 & 35,79 & 23 & 37,09 & 12 & 21,82 & 9 & 34,61 & 4 & 25,00 \\
\hline com. & 15 & 13,52 & 33 & 34,74 & 13 & 20,97 & 12 & 21,82 & 3 & 11,55 & 5 & 31,25 \\
\hline c-a. & 7 & 6,30 & 10 & 10,52 & 0 & 0 & 4 & 7,27 & 2 & 7,70 & 1 & 6,25 \\
\hline prep. & 2 & 1,80 & 1 & 1,05 & 2 & 3,22 & 0 & 0 & 0 & 0 & 0 & 0 \\
\hline tem. & 24 & 21,63 & 5 & 5,27 & 7 & 11,30 & 5 & 9,10 & 4 & 15,38 & 0 & 0 \\
\hline top. & 22 & 19,82 & 10 & 10,52 & 15 & 24,20 & 12 & 21,82 & 7 & 26,92 & 4 & 25,00 \\
\hline ref. & 4 & 3,60 & 2 & 2,11 & 0 & 0 & 4 & 7,27 & 1 & 3,84 & 1 & 6,25 \\
\hline coor. & 6 & 5,40 & 0 & 0 & 2 & 3,22 & 6 & 10,90 & 0 & 0 & 1 & 6,25 \\
\hline Total & 111 & 100 & 95 & 100 & 62 & 100 & 55 & 100 & 26 & 100 & 16 & 100 \\
\hline
\end{tabular}

Os resultados apontam para a preferência de algumas categorias de relaçóes por alguns episódios, revelando tendências na forma como os jornalistas articulam os constituintes textuais no interior de cada episódio. Em outros termos, indicam que, em cada episódio, os constituintes costumam se articular mais por meio de algumas categorias de relaçóes e menos por outras. A avaliação, por exemplo, apresentou concentração elevada de relaçóes de argumento (35,79\%) e comentário (34,74\%). Na complicação, predominam as relaçóes de argumento (27,93\%), tempo $(21,63 \%)$ e topicalização $(19,82 \%)$. Já os episódios resolução, sumário e estágio final não apresentaram qualquer relação de preparação. 


\subsection{Discussão dos resultados da análise relacional da narrativa jornalística}

Apresentados os resultados quantitativos do estudo da forma de organização relacional das sequências narrativas, é importante desenvolver uma discussão desses dados, a fim de buscar explicações para os fenômenos apenas constatados anteriormente. Para isso, focalizarei cada uma das categorias genéricas de relaçóes identificadas na análise das sequências: argumento, comentário, topicalização, tempo, contra-argumento, preparação e reformulação.

\subsubsection{Argumento}

Conforme Roulet (Roulet et al., 2001; Roulet, 2003), a categoria genérica de argumento abarca um conjunto amplo de relaçóes específicas chamadas de "causa (deliberada e não deliberada), explicação, justificação, motivação, consequência, objetivo, resultado (deliberado e não deliberado), condição, restrição, argumento, argumento suplementar, argumento decisivo, exemplo" (Roulet, 2003, p. 157). Como característica comum, essas relaçóes correspondem a manobras discursivas que o produtor do discurso realiza na busca por convencer o outro a aceitar a veracidade ou a consistência das informaçóes veiculadas. Assim, as diferentes relaçóes específicas recobertas pela categoria de argumento buscam dar conta do fato de que, para convencer o interlocutor, o locutor realiza distintas açóes ou manobras argumentativamente orientadas, tais como exemplificar, justificar, concluir, explicar, restringir etc. (Cunha, 2010).

Nas sequências narrativas estudadas nesta pesquisa, há maior porcentagem de relações argumentativas. Das 449 relações identificadas, 127 (28,30\%) pertencem à categoria de argumento (cf. Tabela 1). Esse resultado contraria a ideia, geralmente calcada na observaçáo de textos literários pouco complexos, de que sequências narrativas apresentariam um predomínio de relaçóes temporais, independentemente do gênero a que pertençam os textos analisados. $\mathrm{Na}$ verdade, o que o resultado revela é que o gênero tem impacto forte sobre a construção das sequências e, mais especificamente, sobre a forma como o produtor do discurso vai articular seus constituintes textuais.

No caso da reportagem, o jornalista procura informar o leitor sobre a atualidade, captá-lo e satisfazer suas exigências de credibilidade (Charaudeau, 2006). Essa busca traz restriçôes importantes para a escrita. Por um lado, ele não pode narrar acontecimentos com o objetivo de apenas informar, já que a exigência de credibilidade o obriga a justificar as afirmaçóes, explicitando sua fonte, e a busca por captar o leitor o obriga a convencê-lo de que a forma como a realidade é reconstruída 
é mais convincente ou próxima do "real" do que a dos veículos de comunicação concorrentes. Por outro lado, o jornalista não pode se limitar a produzir avaliaçóes que expressem um ponto de vista pessoal ou da classe (social e profissional) a que pertence, uma vez que a busca por informar exige que o profissional trate de acontecimentos atuais que sejam do interesse amplo dos cidadáos.

Em virtude dessas dessas pressões, o jornalista parece ser levado, então, a optar por um caminho intermediário. No nível relacional, produz sequências narrativas, articulando seus constituintes textuais predominantemente por relaçôes de argumento. Essa opçáo lhe permite, ao mesmo tempo, informar, já que a matéria-prima das sequências narrativas são acontecimentos, satisfazer a exigência de credibilidade do leitor e captá-lo, uma vez que esses acontecimentos são alvo de explicações, ponderaçóes, comparaçôes, exemplificaçóes, restriçôes etc.

No processo de construção das sequências narrativas de reportagens, as relaçóes de argumento ganham, portanto, papel importante na articulação dos episódios. Em alguns casos, um episódio, como a resoluçáo, vai funcionar como a conclusão para as informaçóes expressas em episódios anteriores?:

(01) (EI) (01) Apenas em 2005 (02) se começou a tirar a ideia do papel, (Com) (03) mas a iniciativa esbarrou em uma série de pendências judiciais, (Av) (04) promovidas pelos chatos de plantáo. (Res) (05) A consequência é que somente 28 dos 309 quiosques previstos ficaram prontos. (Veja, "Sol, mar e organização")

Nessa sequência, a expressão $A$ consequência, que introduz a resolução (ato 05), indica que esse episódio vai trazer a conclusão das informações expressas no estágio inicial, na complicação e na avaliação. Em outras sequências, as informaçôes contidas em um conjunto de episódios vấo exemplificar o que foi dito no primeiro episódio:

(02) (Su) (01) Além disso, [a Defensoria] destaca que a responsabilidade das ocupaçóes ilegais nas margens do Tietê não devem ser atribuídas apenas às comunidades pobres, (02) uma vez que o poder público disponibilizou infraestrutura urbana, (03) como água encanada, escolas, asfaltamento e energia. (Com) (04) No Jardim Romano, por exemplo, (05) o prefeito Gilberto Kassab (DEM) inaugurou no ano passado

9 A numeração presente nesta e nas demais sequências constantes deste trabalho indica que elas foram segmentadas em atos. Quanto às abreviaturas em negrito, referem os episódios do tipo narrativo: $\mathrm{Su}=$ sumário, $\mathrm{EI}$ = estágio inicial, $\mathrm{Com}=$ complicação, $\mathrm{Av}=$ avaliação, Res $=$ resolução, $\mathrm{EF}=$ estágio final. 
um Centro Educacional Unificado (CEU). (06) Na mesma rua Capachós, (07) um conjunto habitacional financiado pela Caixa Econômica Federal também foi inaugurado recentemente. (Res) (08) Os investimentos fizeram com que a prefeitura revisasse os valores de imóveis na região, (09) com vistas ao cálculo do IPTU de 2010. (10) A valorizaçáo chega a 187\%. (EF) (11) Só que, hoje, tanto a escola como a Cohab têm a entrada bloqueada pelo lodo. (Carta Capital, "São Paulo na lama")

No trecho, os investimentos no Jardim Romano, expressos nos episódios complicação, resolução e estágio final, constituem um exemplo do que foi dito no sumário, a saber: "a responsabilidade das ocupações ilegais nas margens do Tietê não devem ser atribuídas apenas às comunidades pobres”, mas também ao poder público. A expressão por exemplo, no ato (04), explicita essa relação.

Em outras sequências, o estágio inicial ocupa a posição final da sequência e funciona como a explicação ou a causa para os acontecimentos narrados em episódios anteriores:

(03) (Su) (01) Entre eles, (02) Angra dos Reis é o caso mais dramático (03) e, também, o retrato mais preciso do conjunto de fatores que desencadeia esse tipo de tragédia. (Com) (04) Ali, (05) morreram 52 pessoas, na virada do ano, vítimas de deslizamentos de encostas. (Av) (06) Tudo era previsível. (EI) (07) Na bela regiáo em torno da Baía de Angra, com suas 365 ilhas e mais de 2000 praias, (08) chove quase o dobro da média do Rio de Janeiro, (09) e a instabilidade das encostas é conhecida. (10) Em 2002, (11) 39 pessoas morreram em Angra num deslizamento com características semelhantes às de agora. (Veja, "Trágico, absurdo, previsível")

Nessa sequência, a morte de 52 pessoas em Angra dos Reis, vítimas de deslizamentos de terra (complicação e avaliação), tem como causa a intensidade da chuva na região, que torna instáveis suas encostas (estágio inicial).

Quanto à marcação linguística, as sequências narrativas estudadas apresentaram quantidade elevada de relações argumentativas marcadas por conectores e expressóes conectivas. Das 127 relaçóes, 74 (58,26\%) são marcadas (cf. Tabela 3), o que revela a busca do jornalista por guiar a interpretação do leitor, fornecendo as marcas necessárias para o reconhecimento de uma relação específica. Assim, as sequências narrativas apresentaram marcas de diferentes relaçôes argumentativas específicas, tais como explicação (pois), causa (porque, uma vez que), argumento suplementar (além de, além disso), argumento potencial (se), exemplificação (por exemplo), finalidade (para), restrição (mesmo se, sem que), argumento por autoridade (segundo) etc. 


\subsubsection{Comentário}

No modelo modular, considera-se que a relação de comentário, assim como a de preparação, não possui marca específica e se caracteriza, portanto, pela posição do constituinte textual. Assim, o constituinte que exerce a função de comentário é subordinado e ocorre posposto ao principal. Roulet et al. (2001, p. 171) oferecem este exemplo de intervenção cujos constituintes se articulam por uma relação de comentário: "[01] Encontrei Paulo ontem à noite. [02] Isso foi realmente inesperado [comentário].” Nessa intervenção, o locutor, por meio do segundo ato, comenta a informação expressa no primeiro.

A análise das sequências narrativas mostrou que comentar é uma ação que os jornalistas realizam com frequência quando narram em uma reportagem. A relação de comentário foi a segunda mais frequente no corpus, 108 (24,05\%), ficando atrás apenas da de argumento (cf. Tabela 1). E, não por acaso, a avaliação é o episódio do tipo narrativo que mais funcionou como comentário. Das 43 avaliações, 29 (67,44\%) exercem a função de comentário para outros episódios (cf. Tabela 4). Por meio da avaliação, o jornalista pode apresentar algum personagem comentando acontecimentos expressos na intervençâo ou no ato anterior:

(04) (Su) (01) Enquanto a população se vira para ajustar a renda ao novo cenário, (02) o governo não faz esforço para conter suas despesas. (EI) (03) No ano passado, (Com) (04) os gastos públicos chegaram a cerca de R $\$ 145$ bilhôes, (05) 17\% a mais que em 2008. (Av) (06) "Não há mágica para melhorar a situação fiscal. (07) Tem de haver redução de gastos (08) e, eventualmente, aumento de arrecadação", (09) diz Zeina Latif, economista-chefe do banco ING no Brasil. (Época, "O bolívar forte ficou fraco")

Nessa sequência, o jornalista, após mencionar os problemas econômicos enfrentados pelo governo venezuelano, traz na avaliação o comentário de um economista. Mas muitas vezes o responsável pela avaliação, que vai exercer a função de comentário, é o próprio jornalista:

(05) (EI) (01) Apenas em 2005 (02) se começou a tirar a ideia do papel, (Com) (03) mas a iniciativa esbarrou em uma série de pendências judiciais, (Av) (04) promovidas pelos chatos de plantão. [...] (Veja, "Sol, mar e organização") 
Nesse trecho, que trata da fiscalizaçáo dos quiosques na orla do Rio de Janeiro, é o próprio jornalista quem comenta o ato (03), criticando, em (04), a atitude dos chatos que, por meio de pendências judiciais, impediram a instalação de novos quiosques.

Também não por acaso, o episódio cujos constituintes se articulam com maior frequência por relaçôes de comentário é a avaliação (cf. Tabela 5). Essa característica da avaliação encontra duas explicaçóes complementares. Em primeiro lugar, a natureza referencial desse episódio, especializado em apresentar explicações, críticas e denúncias (Cunha, 2013, 2015), justifica um perfil relacional mais comentativo. Em segundo, a função de comentário que a avaliação costuma exercer na macroestrutura hierárquico-relacional (cf. Tabela 4) pode levar seus constituintes a se articular por relaçôes de comentário.

Quanto à marcação linguística, é pouco sustentável o postulado do modelo modular de que a relação de comentário não tem marcação específica. Uma evidência nesse sentido é oferecida por Marinho (2002), que mostra que o conector onde pode funcionar como marca dessa relação. Um dos exemplos dados pela autora (Marinho, 2002, p. 105), que estudou o uso desse conector em textos acadêmicos, é este: "(14) A radicalização do ensino na sua forma tradicional, (15) onde a gramática está em posição de destaque, (16) deve ser revista”. No trecho, o autor utiliza o ato (15) para comentar a radicalização do ensino em sua forma tradicional, informação expressa em (14). Essa relação de comentário é marcada pelo onde.

Nas sequências narrativas analisadas, vários comentários são introduzidos pelo conector $e$ e por outros que, no nível sintático, são pronomes relativos: onde, cujo, que, o que, no qual. Um exemplo de relação de comentário marcada por pronome relativo encontra-se no trecho seguinte, parte de uma sequência sobre uma enchente:

(06) (Com) [...] (02) uma reportagem publicada pelo portal UOL revelou que as seis comportas da barragem da Penha foram fechadas na madrugada da enchente, (03) e só foram reabertas dois dias depois. (Av) (04) A ação teria evitado o alagamento da marginal do Tietê, (05) onde o governo realiza um conjunto de obras viárias orçado em 1,3 bilhão de reais. (Carta Capital, "São Paulo na lama")

A informação expressa no ato (05), introduzido pelo onde, funciona como um comentário para a informação contida no ato (04). 


\subsubsection{Topicalização}

$\mathrm{Na}$ relação de topicalização, um constituinte subordinado ativa uma informação (um objeto de discurso) que será abordada, em seguida, no principal. Nesse sentido, embora a noção de "relação de topicalização" seja própria da forma de organizaçáo relacional, ela "repousa essencialmente sobre uma ancoragem informacional: a informação ativada pelo primeiro ato constitui o ponto de ancoragem imediato, ou seja, o tópico do segundo ato" (Grobet, 1999, p. 106) ${ }^{10}$. Ainda segundo Grobet, os elementos topicalizados podem exercer diferentes funções específicas, como (i) ativar um objeto de discurso apresentado como aquele de que o locutor vai falar ou (ii) ativar um objeto de discurso inicial apresentado como o "pano de fundo" do que segue.

Dos episódios das sequências narrativas analisadas, apenas o estágio inicial, em onze ocorrências, se articula à intervenção ou ao ato seguinte por meio da relação de topicalização (cf. Tabela 4). Desses onze, muitos atuam como pano de fundo para a informação seguinte:

(07) (EI) (01) No Rio de Janeiro, cenário da mais recente tragédia, (Com) (02) só se gastou 1,17\% em ações preventivas. (Av) (03) O governador do Rio, Sérgio Cabral, culpou os "40 anos de omissão dos políticos" no Brasil. (Época, "É possível evitar?")

Nessa sequência, o estágio inicial se textualiza em um ato topicalizado (ato 01). Este ativa um objeto de discurso (Rio de Janeiro) que não constitui a informação sobre a qual se vai falar em seguida, mas um pano de fundo ou um enquadre espacial, em cujo interior os acontecimentos sequentes devem ser interpretados.

Mas também ocorrem estágios iniciais topicalizados cuja função é ativar um objeto de discurso apresentado como aquele de que o locutor vai falar:

(08) (EI) (01) Crispim mora com a família em uma casa de quatro cômodos no Jardim Pantanal, próximo de onde cumpria a amarga tarefa de demolição. (Com) (02) No dia da cheia, (03) seus móveis ficaram meio metro submersos. (04) Somente após duas semanas, (05) a água saiu da residência. (Res) (06) Passados 35 dias da enchente, (07) a inundação persistia no quintal e nas ruas do bairro, (08) tomadas por um lodo escuro e fétido, mistura das águas da chuva com o esgoto que deixou de ser bombeado por

10 Para o modelo modular, o tópico constitui a informação mais diretamente pertinente ou acessível da memória discursiva em que o ato se encadeia. Não se refere, portanto, a um segmento linguístico, mas a uma informação previamente estocada na memória discursiva. 
uma estação de tratamento atingida pelas chuvas. (EF) (09) O cenário é recorrente em ao menos sete bairros do distrito Jardim Helena, na divisa com os municípios de Guarulhos e Itaquaquecetuba, Grande São Paulo. (Carta Capital, "Sáo Paulo na lama”)

Nessa sequência, a informação ativada no estágio inicial (ato 01) se liga ao restante da sequência por uma relação de topicalizaçáo, porque, por meio do episódio, o jornalista indica que vai falar de Crispim e sua família. Esta macroestrutura busca dar conta de tal interpretação ${ }^{11}$ :

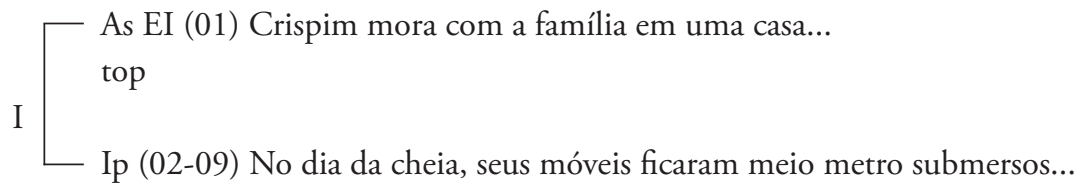

No interior dos episódios, também ocorrem constituintes textuais topicalizados exercendo essas duas funçóes básicas de ativar um pano de fundo:

(09) (01) Na quarta-feira 13, (02) o presidente Lula convocou os ministros da Defesa, Nelson Jobim, e da Secretaria Especial dos Direitos Humanos, Paulo Vannuchi. (IstoÉ, "O passado ainda presente")

ou ativar o tópico do constituinte textual seguinte:

(10) (01) São Luiz do Paraitinga não existe mais. (02) Os moradores da pequena cidade histórica no interior de São Paulo não se cansam de repetir esta frase (IstoÉ, "Eles não deveriam estar aqui")

Esse último exemplo é particularmente interessante, porque revela que o objeto de discurso topicalizado pode ser não só a informação ativada por um sintagma, mas uma declaração dada por uma fonte jornalística, declaração que, no ato seguinte, é categorizada pelo jornalista como frase.

No que se refere à marcação linguística, as sequências narrativas não apresentaram qualquer expressão conectiva tipicamente introdutora de tópico,

11 Nesta e nas demais estruturas discutidas neste trabalho, constam estas abreviaçóes: informações hierárquicas ( $\mathrm{I}=$ intervenção; $\mathrm{A}=$ ato; $\mathrm{p}=$ principal; $\mathrm{s}=$ subordinado), informaçóes relacionais $(\mathrm{com}=$ comentário, $\arg =$ argumento, $\mathrm{c}-\mathrm{a}=$ contra-argumento, ref $=$ reformulação, tem $=$ tempo, top $=$ topicalizaçáo, pre $=$ preparação $)$, informaçóes sequenciais $(\mathrm{Su}=$ sumário, EI = estágio inicial, Com = complicação, Av = avaliação, Res = resolução, $\mathrm{EF}=$ estágio final). 
como quanto a, a respeito de, no que tange a, acerca de etc., nem estruturas clivadas, como "É de bolo que eu gosto". Mas foram bastante numerosos os deslocamentos à esquerda de constituintes textuais. Para o modelo modular, o deslocamento à esquerda, como já informado, é uma construção sintática que evidencia, marcando, a relação de topicalização.

No corpus, o fenômeno do deslocamento à esquerda ocorre em 62 (93,93\%) das 66 relaçốes de topicalização identificadas (cf. Tabela 3). É importante observar que grande parte desses constituintes deslocados para a margem esquerda de outros é formada por sintagmas adverbiais, tais como: No litoral paulista, Em Belo Horizonte, Já no dia 5, Na quarta-feira 13, No dia 5 de novembro de 2008. Todos eles vão exercer a função de pano de fundo ou, na proposta de Charolles (2006), de marcadores de universo de discurso. Nas sequências narrativas de reportagens, essas expressôes adverbiais são importantes para a produção de sentidos exatamente porque, como revela esse autor, ativam um enquadre espacial ou temporal, atuando, ao mesmo tempo, na organização e na segmentação das informações mobilizadas nas sequências. $\mathrm{O}$ papel estruturante que a topicalização de adjuntos adverbiais pode exercer nas sequências narrativas de reportagens se verifica neste exemplo:

(11) (EI) (01) Quando Tom Jobim e Vinicius de Moraes compuseram Garota de Ipanema, em 1962, (02) o Rio de Janeiro tinha metade do número de habitantes de hoje. (03) Havia espaço de sobra (04) para que a musa andasse, em doce balanço, a caminho do mar (05) - sem tropeçar. (Com) (06) Nos últimos anos, porém, (07) as praias cariocas tornaram-se lugares quase intransitáveis. (08) Não apenas porque há mais gente. (09) O maior tumulto é provocado pela turba de barraqueiros, camelôs e flanelinhas que tomou conta do pedaço. (Av) (10) A ideia de que a orla do Rio era um espaço de convivência extremamente democrático serviu apenas como pretexto para a falta de organização. (11) A baderna se espalhou. (Res) (12) Neste verão, (13) a prefeitura do Rio resolveu pôr ordem na casa. (14) A primeira providência foi dar um banho de loja nas barracas que funcionam como ponto de venda de bebidas e de aluguel de cadeiras e guarda-sóis. (15) Em vez das tendas improvisadas e das caixas de isopor imundas, espalhadas pela areia, (16) só serão permitidas barracas padronizadas e caixas térmicas de plástico. (17) O número de barraqueiros, agora uniformizados, foi reduzido. (18) No primeiro trecho em implantação, (19) que compreende as praias do Arpoador, Ipanema e Leblon, (20) baixou de 300 para 193. (Veja, "Sol, mar e organização")

Os acontecimentos narrados se passam em três momentos distintos. $\mathrm{O}$ primeiro é a época em que Tom Jobim e Vinicius de Moraes compuseram Garota de Ipanema, o segundo é mais recente, quando "as praias cariocas tornaram-se lugares quase intransitáveis", e o terceiro é bem recente e corresponde ao momento de 
produção da reportagem (janeiro de 2010). Para permitir ao leitor compreender quando começa e termina cada um desses intervalos temporais, o jornalista utiliza o recurso de segmentar temporalmente a sequência, deslocando à esquerda adjuntos adverbiais, que vão funcionar como pano de fundo temporal para o que será dito em seguida.

Assim, após abordar a época da composição da canção, a expressão adverbial Nos últimos anos (ato 06) indica o fim desse primeiro momento e, ao mesmo tempo, que as informaçôes seguintes se passam em um segundo momento. Com a expressáo Neste verão (ato 12), o autor referencia o fim desse segundo momento e a abertura de um terceiro, correspondente ao momento de produção da reportagem.

\subsubsection{Tempo}

Em estudo em que reviso a forma como o modelo modular aborda as relaçóes temporais (Cunha, 2012a, p. 43), proponho esta definição para a categoria genérica de tempo:

por meio das relaçóes específicas recobertas por essa categoria [sucessão, anterioridade, simultaneidade, progressão etc.], o locutor/autor localiza no tempo, relacionando-os uns aos outros, açốes, eventos e estados de coisas representados no discurso, dispondo-os na ordem em que deseja que o interlocutor/leitor os compreenda ou na ordem que considera a mais adequada ao seu projeto de dizer.

As relações temporais exercem papel importante na articulação da macroestrutura hierárquico-relacional das sequências narrativas de reportagens, porque podem sinalizar que os acontecimentos ativados em grandes intervençóes das sequências se dão em intervalos temporais diferentes. Vejamos como isso ocorre neste exemplo:

(12) (Su) (01) Também as Forças Armadas, tantos anos depois do fim da ditadura, continuam a cometer excessos. (02) O jovem carioca J.O., 17 anos, foi vítima dos militares. (EI) (03) No dia 5 de novembro de 2008, (04) ele e um amigo pularam o muro de um quartel do Exército desativado, em Realengo, zona oeste do Rio, (05) para fumar maconha. (Com) (06) Foram flagrados pelos sentinelas (07) e passaram a ser agredidos. (Av1) (08) "Fomos torturados com choques elétricos, (09) o que fez com que a pele de minhas costas pegasse fogo. (10) Pensei que ia morrer naquele momento", (11) diz. (Res) (12) J.O. sobreviveu, (13) mas com sequelas: (14) perdeu $20 \%$ da visão do olho esquerdo, teve cortado um pedaço da orelha e tem marcas nas 
costas. (Av2) (15) "Queremos que o Exército pague os remédios e o tratamento dele", (16) reclama Maria Célia Furtado, a mãe adotiva. (EF) (17) Dois anos depois, (18) o processo corre na auditoria militar, sem previsão de término. (Av3) (19) Procurado por ISTOÉ, (20) o Exército preferiu não se manifestar sobre o assunto. (IstoÉ, "O passado ainda presente")

Nesse segmento, o jornalista articula os episódios de maneira cronológica, sinalizando para o leitor que os acontecimentos narrados se produziram um depois do outro em momentos diferentes. Reconstituindo essa cadeia temporal, percebe-se que, primeiro, os jovens pularam o muro do quartel (estágio inicial). Em seguida, foram flagrados e agredidos (complicação). Depois disso, um dos jovens sobreviveu, mas com sequelas (resolução). Finalmente, após dois anos, o processo contra o Exército corre na auditoria militar (estágio final). Represento essa interpretação por meio da seguinte macroestrutura.

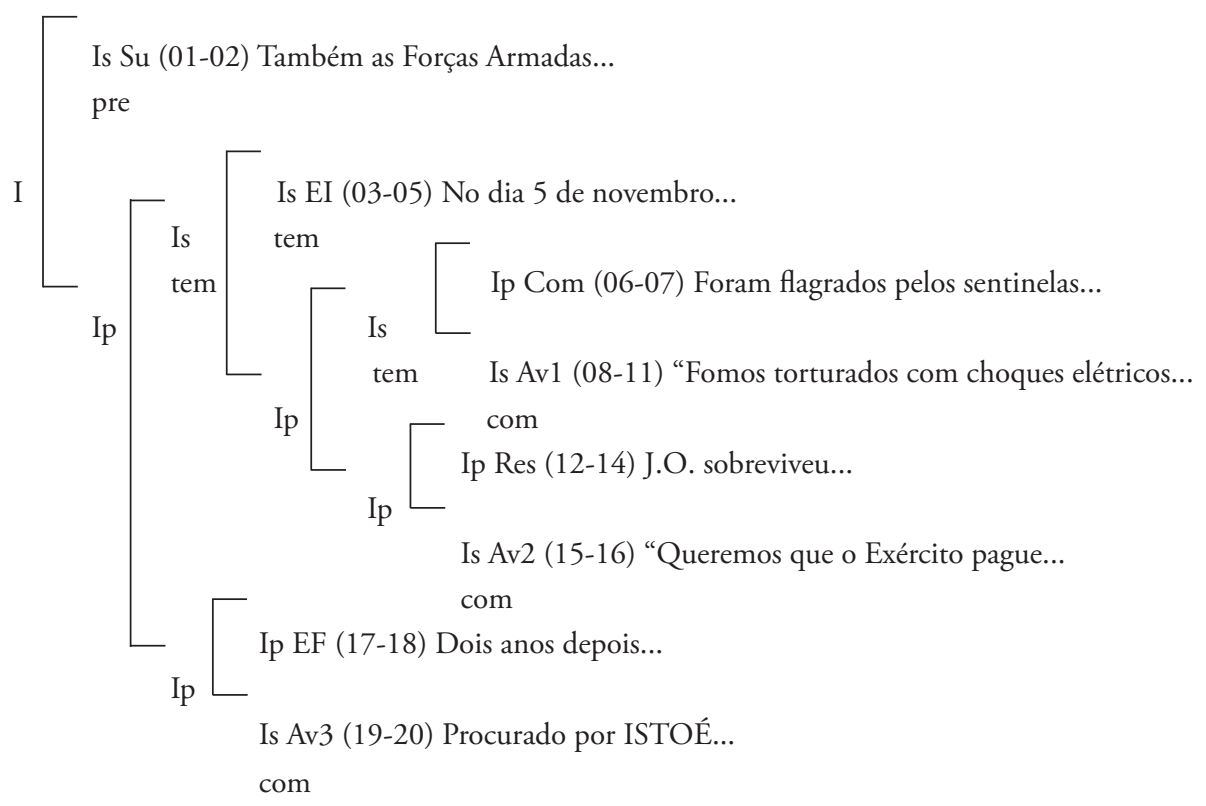

Todos os episódios das sequências analisadas trazem relaçóes de tempo, com exceção do estágio final. Entretanto o que apresentou maior concentração de relaçôes temporais foi a complicação. Nela, 24 (21,63\%) das 111 relaçóes de discurso são temporais (cf. Tabela 5). A complicação aborda predominantemente os acontecimentos que o jornalista quer informar. Por isso, era de esperar que esse 
episódio exibisse uma porcentagem elevada de relaçóes temporais articulando esses acontecimentos. É o que mostra o exemplo:

(13) (EI) (01) Foi assim no caso de Andreu Luiz Silva de Carvalho, (02) que tinha 17 anos (03) quando foi torturado até a morte no Departamento-Geral de Açôes Socioeducativas (Degase) (...) (Com) (07) Entrou no Degase (ex-Funabem) no primeiro dia de 2008 (08) e recebeu como cartão de visita um soco no rosto. (09) Revidou. (10) Foi espancado (11) e não viveu para contar a história. (Av1) (12) Segundo testemunhas, (13) cinco funcionários da instituição, tendo à frente o agente Wilson Santos, submeteram Andreu a uma bárbara sessão de espancamento. (IstoÉ, "O passado ainda presente")

Na sequência, todas as informaçóes ativadas na complicação são articuladas por relações de tempo, o que se comprova com a possibilidade de inserção de conectores temporais no início dos atos.

(14) Entrou no Degase (ex-Funabem) no primeiro dia de 2008 e (depois) recebeu como cartáo de visita um soco no rosto. (Em seguida) Revidou. (Depois) Foi espancado e (em seguida) não viveu para contar a história.

Quanto à marcação linguística, verificou-se que 35 (57,37\%) relações temporais são marcadas por conectores (cf. Tabela 3). Algumas hipóteses podem ser levantadas para explicar a concentração expressiva de conectores. A primeira é a de que alguns têm como característica imprimir nuances aspectuais que não seriam produzidas sem eles (Fiorin, 2010). É o caso de a partir de ou à medida que, que permitem criar o efeito de sentido de que algo se inicia a partir de um momento específico e continua a ocorrer durante certo intervalo de tempo. A segunda hipótese para essa concentração está no fato de que algumas relaçóes temporais específicas parecem exigir o emprego de conectores, a exemplo das relaçóes de simultaneidade e de anterioridade. Vejamos esta sequência:

(15) (EF) (01) Ao menos uma dezena de casas já havia sido demolida por ordem da prefeitura, (Res) (02) após a remoção das famílias que concordaram em receber um auxílio aluguel de 300 reais para abandonar a várzea do rio Tietê (Carta Capital, "São Paulo na lama")

No exemplo, a relação específica de anterioridade é marcada pelo conector após. A ordem de apresentação dos acontecimentos na sequência contraria a ordem em que supostamente esses acontecimentos ocorreram. Mas o após, sinalizando essa diferença, indica que, primeiro, as famílias foram removidas (ato 02) e, depois, 
as casas foram demolidas (ato 01). É mais difícil inferir essa relação na ausência do conector:

(16) Ao menos uma dezena de casas já havia sido demolida por ordem da prefeitura. As famílias que concordaram em receber um auxílio aluguel de 300 reais para abandonar a várzea do rio Tietê foram removidas.

Com a referida ausência, parece ganhar força uma interpretação sucessiva (um acontecimento depois do outro). Nesse sentido, alguns conectores temporais, à maneira de alguns reformulativos (Rossari, 1993), parecem ser criadores de relaçóes de discurso e não apenas marcadores de relaçóes que existiriam sem eles.

\subsubsection{Contra-argumentaçáo}

No trabalho que constitui uma das bases do modelo modular ou sua fase inicial (Roulet et al., 1985), a relação de contra-argumentação articula dois constituintes da seguinte forma: "na sequência p C q, q está em uma relação de contradição com p tal ou que (i) q invalida a relaçâo de implicação de p com não-q convocada pela enunciação de $\mathrm{p}$ ou (ii) o ato de argumentação realizado em q invalida o ato de argumento realizado em p" (Roulet et al., 1985, p. 133-134). Essa categoria genérica engloba 35 relaçôes presentes nas sequências narrativas estudadas. $\mathrm{O}$ episódio em que há maior número de relaçóes contra-argumentativas (dez, sendo 10,52\%) é a avaliação (cf. Tabela 5). Muitas dessas ocorrem na fala de personagens do mundo representado, como na sequência:

(17) (EI) (01) Diante das reclamaçôes de moradores, (Com) (02) a Defensoria Pública do Estado de São Paulo entrou com uma ação pedindo a suspensão das remoçóes (03) até que o processo seja discutido com a população. (Av) (04) "Estamos falando de pessoas, e não de objetos que podem ser removidos de um lugar para o outro. (05) Eles querem sair do local, (06) mas com um mínimo de dignidade", (07) afirma Carlos Henrique Loureiro, coordenador do Núcleo de Habitação e Urbanismo da Defensoria. (Carta Capital, "São Paulo na lama")

Nesse exemplo, o ato (06) invalida a implicação que se pode tirar de (05) e, em certa medida, de (04) também: a de que moradores da área de risco poderiam querer sair dessa área de qualquer forma. Invalidando essa implicação, o responsável pela fala diz que os moradores querem sair, de fato, mas com um mínimo de dignidade. Por meio dessa afirmação, o personagem se posiciona explicitamente contra as açóes da prefeitura da cidade de São Paulo, agente das 
remoçôes. A natureza polêmica e polifônica da contra-argumentação, que opóe claramente dois pontos de vista (Ducrot et al., 1980), é uma explicação para a quantidade expressiva de relações de contra-argumentação em afirmaçôes cuja instância enunciativa responsável não é o jornalista.

$\mathrm{Na}$ mesma perspectiva, é interessante observar que, em muitas relações de contra-argumentação, o jornalista ou opóe dois pontos vista atribuíveis a personagens distintos e antagônicos ou contra-argumenta utilizando acontecimentos que supostamente ocorreram e que não são passíveis de contestação. Um exemplo do primeiro caso é esta sequência:

(18) (EI) (01) No último dia 5, (Com) (02) parte de uma ponte de 314 metros sobre o Rio Jacuí, a 240 quilômetros de Porto Alegre, despencou. (03) Entre vinte e trinta pessoas estavam sobre a estrutura de 132 metros que desabou. (Res) (04) Três delas morreram. (05) Outras duas ainda estavam desaparecidas na noite da sexta-feira. (Av1) (06) O governo gaúcho atribui o desastre à elevação das águas do Jacuí. (07) Por essa versão, (08) o rio subiu até a pista, (09) que se partiu. (Av2) (10) Os sobreviventes dáo outro testemunho. (11) "As águas estavam 5 metros abaixo do concreto", (12) diz o aposentado Élio Prade, de 57 anos. (Veja, "Trágico, absurdo, previsível").

No trecho, o jornalista não emite seu ponto de vista acerca das causas da queda da ponte, ao articular a primeira avaliação (Av1), atribuível ao governo gaúcho, e a segunda (Av2), atribuível aos sobreviventes. O jornalista atua na articulação dessas avaliaçóes, colocando-as lado a lado, para que o leitor conclua por si só quem tem razão. Inclusive, a ausência de um conector contra-argumentativo, como o mas, no início da segunda avaliaçáo, pode ser entendida como recurso para atenuar a força dessa avaliação na condição de contra-argumento.

Entretanto, ainda que o jornalista não explicite seu ponto de vista, a forma como expóe e articula as avaliaçóes diz muito sobre seu posicionamento. Em primeiro lugar, na sequência p C q, a segunda avaliação ocupa a posição q, que é o constituinte que, mais forte que $\mathrm{p}$, o contradiz ou nega uma implicação a ele subjacente. Em segundo, a explicação do governo para a queda da ponte é categorizada pelo jornalista como versão, o que diminui a credibilidade dessa explicação diante da dos sobreviventes, categorizada como testemunho.

Como disse, também há casos em que o jornalista contra-argumenta, utilizando para isso acontecimentos que, por terem ocorrido, não admitem contestação. Vejamos: 
(19) (Com) (01) Antes de remover as casas, (02) o governo "congelou" a área invadida. (03) Cerca de 70 homens da Polícia Militar Ambiental circulavam diariamente na região - a pé e motorizados - (04) para interditar novas edificaçóes. (05) O Instituto de Pesquisas Tecnológicas de São Paulo (IPT) identificou ocupaçōes em encostas, com alta probabilidade de desabamento. (06) As famílias nesses locais seriam prioritárias para desocupaçáo. (Res) (07) O programa seguiu com a construção de novos bairros. (EF) (08) A entrega das casas, prometida para o ano passado, ainda não foi cumprida. (Época, “É possível evitar?")

Na relação entre os atos (07) e (08), o não cumprimento da entrega das casas (ato 08) constitui um fato que, por poder ser comprovado, foi utilizado pelo jornalista como contra-argumento para negar a implicação decorrente do ato (07), a saber: se o governo prometeu que as casas estariam prontas no ano passado, espera-se que neste ano já estejam.

Quanto à marcação linguística das relaçóes de contra-argumento, o conector que, nas sequências analisadas, apresentou maior número de ocorrências foi o mas (cf. Tabela 2), típico dessa categoria de relações (Guimarães, 2007; Reboul e Moeschler, 1998). Ocorreu ainda na expressão mas mesmo assim, em que o mesmo assim parece reforçar o valor contra-argumentativo do mas. Todos os outros identificados apresentaram apenas uma ocorrência.

\subsubsection{Preparaçáo}

No modelo modular, considera-se que a relação de preparação, assim como a de comentário vista anteriormente, não apresenta marcador específico, como conectores ou estruturas sintáticas. A relação de preparação se caracteriza pela posição inicial do constituinte subordinado em relação ao principal. Para expor essa propriedade, Roulet (apud Roulet et al., 2001, p. 171) mostra alguns exemplos, dentre os quais destaco este, por ser o início de uma sequência narrativa: "Era uma bela manhã de inverno [preparação]. Eu saí (no começo de uma narrativa)..." Nesse início de sequência, um ato, que traz informação relativa ao momento em que se passa a história, ou seja, o estágio inicial, prepara o leitor, sinalizando que os acontecimentos centrais da história, a serem narrados nos episódios seguintes, vão ocorrer numa manhã de inverno.

Nas sequências narrativas analisadas, o episódio que costuma exercer a função de preparação com maior frequência é o sumário. Dos 22 presentes nas sequências, dezessete $(77,27 \%)$ exercem essa função (cf. Tabela 4). A explicação para a frequência de sumários com função preparatória parece estar na natureza 
referencial desse episódio. O jornalista, por meio do sumário do tipo narrativo da reportagem, oferece indicaçóes sobre o conteúdo da sequência, podendo (i) tentar despertar a curiosidade do leitor sobre as causas de um acontecimento, (ii) anunciar que os episódios seguintes vão exemplificar um problema mencionado no cotexto, (iii) explicar o sentido de elemento linguístico ou (iv) apresentar um problema geral a ser particularizado nos episódios seguintes (Cunha, 2013, 2015).

Como todas essas ações parecem ser motivadas pela busca de aguçar no leitor da reportagem a vontade de saber mais sobre um acontecimento (exigência de captação), compreende-se que o jornalista, na estrutura hierárquico-relacional, ancore o sumário em um constituinte subordinado com função de preparação. É o que se pode ver nesta sequência, que trata da situação econômica da Venezuela.

(20) (Su) (01) Enquanto a população se vira para ajustar a renda ao novo cenário, (02) o governo não faz esforço para conter suas despesas. (EI) (03) No ano passado, (Com) (04) os gastos públicos chegaram a cerca de R $\$ 145$ bilhóes, (05) 17\% a mais que em 2008. (Av) (06) "Não há mágica para melhorar a situação fiscal. (07) Tem de haver redução de gastos (08) e, eventualmente, aumento de arrecadação", (09) diz Zeina Latif, economista-chefe do banco ING no Brasil. (Época, "O bolivar forte ficou fraco")

Nela, o sumário, antecipando o conteúdo dos episódios seguintes, cria a expectativa de que esses episódios vão explicar por que o governo venezuelano não faz esforço para conter suas despesas. Por isso, esse episódio se ancora em um constituinte textual cuja função é a de preparação. Represento essa análise por meio da seguinte estrutura hierárquico-relacional.

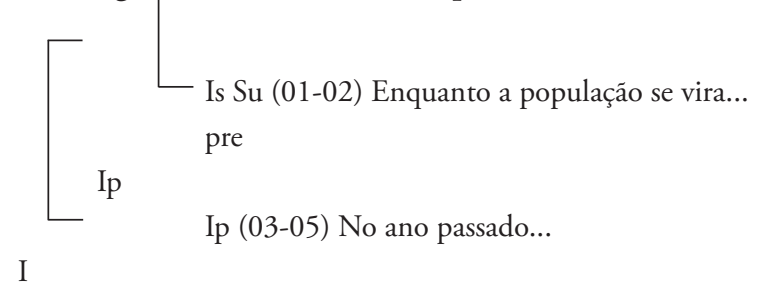

Is Av (06-09) "Não há mágica para melhorar...

com

\subsubsection{Reformulaçáo}

No modelo modular, a categoria genérica de reformulação foi analisada em estudos realizados por Roulet et al. (1985), Roulet (1987) e Rossari (1993). No 
presente trabalho, adoto em especial os postulados desta última, que estudou a categoria de modo mais aprofundado. Para a autora, a reformulação se divide em duas subcategorias: a parafrástica e a não-parafrástica.

A reformulação parafrástica se caracteriza pela existência de uma equivalência semântica entre dois constituintes textuais (atos ou intervençôes). Segundo Rossari (1993), o locutor, por meio desse tipo de reformulação, busca completar, ratificar ou explicar a informação expressa no primeiro constituinte e apresenta as informaçóes dos dois constituintes como devendo ser consideradas equivalentes pelo interlocutor. Nesse tipo de reformulação, os constituintes podem ou não ser articulados por um conector. Em português, alguns conectores que marcam a reformulação parafrástica são: ou seja, isto é, a saber, em outros termos.

Já a reformulação não-parafrástica permite ao locutor operar uma retrointerpretação da informação expressa no primeiro constituinte textual. Nessa retrointerpretação, o locutor realiza no segundo constituinte uma mudança de perspectiva enunciativa em relação à informação expressa no primeiro. Essa mudança de perspectiva se traduz por um distanciamento do locutor quanto ao que foi dito no primeiro constituinte e pode ser mais ou menos forte, dependendo do conector empregado. Em português, alguns conectores que marcam esse tipo de reformulação são: de fato, na verdade, de qualquer forma, enfim, seja como for.

Nas sequências narrativas analisadas, as relaçôes pertencentes à categoria genérica de reformulação foram as menos numerosas (2,89\% - cf. Tabela 1). Isso quer dizer que raramente os jornalistas, ao narrar acontecimentos no interior de uma reportagem, recorrem a essa categoria. Uma razão para isso pode estar no fato de que ela implica que aquele que narra precisa suspender momentaneamente a cadeia dos acontecimentos para dizer de outra maneira, parafraseando ou reavaliando, o acontecimento que acabou de narrar. Essa interrupção da narrativa para dizer algo de outra forma pode ser prejudicial para a exigência de captação do leitor, a qual caracteriza o gênero reportagem (Cunha, 2015). Isso porque quem reformula, ao esclarecer uma informação dada, costuma ponderar essa informação, refletir sobre ela, focalizar um aspecto subjacente ainda não revelado etc. Essas açóes específicas não parecem ser próprias de um gênero como a reportagem, que pressupóe um leitor escolhendo, dentre as múltiplas ofertas de produtos midiáticos, aquele que vai informar de forma mais imediata, direta e com menor quantidade de interrupções ou reformulaçóes. É possível, então, levantar a hipótese de que, mesmo nas sequências pertencentes a outros tipos propostos pelo modelo modular (descrição 
e deliberação), a reportagem não vai exibir frequência de relaçôes de reformulação tấo alta como a de outras categorias ${ }^{12}$.

Outra observação decorrente da análise das sequências é a de que, dos dois tipos de relaçôes de reformulação mencionadas (parafrástica e não-parafrástica), todas as treze encontradas nas sequências são parafrásticas, já que por meio delas o jornalista não opera uma modificação da perspectiva enunciativa desenvolvida no constituinte objeto da reformulação. Um exemplo é esta sequência:

(21) (EI) (01) Já em São Luiz do Paraitinga (02) não havia nenhum indício de que o centro histórico dessa cidade famosa por seu Carnaval estivesse em uma área de risco. (Com) (03) Mas mesmo assim a enxurrada simplesmente destruiu todo o comércio e o seu patrimônio histórico, (Res) (04) abalando de forma consistente a principal indústria do município: (05) o turismo. (IstoÉ, "Eles não deveriam estar aqui")

No trecho, o jornalista revela, no ato (05), qual é a principal indústria de São Luiz do Paraitinga: o turismo. Nesse sentido, a relaçẫo entre (04) e (05) é parafrástica, porque é possível inferir uma relação de equivalência semântica entre a principal indústria do município, expressão mencionada no ato (04), e o turismo, expressão que constitui o ato (05). Essa relação pode ser explicitada por meio da expressão reformulativa a saber.

(22) abalando de forma consistente a principal indústria do município, a saber, o turismo.

A respeito da marcação linguística, nenhuma relação de reformulação identificada foi marcada por conector ou expressão conectiva tipicamente reformulativa (cf. Tabela 2). Entretanto, em algumas sequências, o ato principal, aquele que traz a reformulação, é antecedido por dois-pontos, como ocorre na sequência citada anteriormente. Por ter exatamente como uma de suas funções indicar uma relação de equivalência semântica entre dois termos (Dahlet, 2006), os dois-pontos podem ser entendidos como instrumento heurístico que permite reconhecer uma relação de reformulação parafrástica.

12 Fornecendo evidências a favor dessa hipótese, as cinco reportagens integrantes do corpus de minha pesquisa de mestrado (Cunha, 2008) não apresentam qualquer relação de reformulação. No gênero notícia, próximo da reportagem, Duarte (2008) também não a identificou nos oito exemplares que estudou. 


\section{CONSIDERAÇÓES FINAIS}

Neste trabalho, apresentei um estudo da forma de organização relacional de sequências narrativas de reportagens, a fim de evidenciar que o plano das relações discursivas é fortemente impactado pela dimensão situacional do discurso. Assim, todas as regularidades verificadas na etapa descritiva da análise puderam ser compreendidas, no momento da discussão dos resultados dessa etapa, à luz de propriedades do gênero do discurso a que pertencem as sequências estudadas. Dessa forma, verifica-se que a maneira como o jornalista, ao narrar, estabelece as relaçôes de discurso, tais como as de argumento, contra-argumento, reformulação etc., e as explicita por meio de conectores e estruturas sintáticas é fortemente vinculada à interação de que participa e à concepção de mundo e aos pontos de vista de que ele deseja convencer o leitor.

Nesse sentido, o presente artigo traz um argumento suplementar e pontual, porque calcado na análise da forma de organização relacional, para a hipótese da pesquisa maior em que se insere (Cunha, 2013). Como exposto na introdução, essa pesquisa partiu da hipótese de que cada gênero do discurso possui tipos de discurso específicos. Assim, o tipo narrativo da reportagem possui particularidades que o diferem do de gêneros como o conto ou o boletim de ocorrência, já que não se narra da mesma forma em cada um deles. Trazendo evidências para essa hipótese, o estudo aqui apresentado revelou que as sequências narrativas da reportagem exibem uma série de regularidades em sua forma de organização relacional. Porque essas regularidades se devem ao gênero reportagem, elas ajudam a caracterizar o modo como o jornalista narra, ao escrever um exemplar desse gênero. Sendo assim, tornam-se duvidosas abordagens que partem da hipótese de que os tipos seriam transversais em relação aos gêneros e de que, por isso mesmo, um mesmo tipo narrativo se atualizaria em quaisquer gêneros em que ocorre a atividade de narrar.

\section{REFERÊNCIAS}

Berrendoner A. "Connecteurs pragmatiques" et anaphore. Cahiers de linguistique française. 1983; 5:215-246.

Bronckart JP. Atividade de linguagem textos e discursos: por um interacionismo sóciodiscursivo. São Paulo: EDUC, 2007.

Camacho RG. Estruturas coordenadas aditivas. In: Neves MHM, organizadora. Gramática do português falado: novos estudos. São Paulo: Unicamp/FAPESP 1999. 7 
vol. p. 351-406.

Camacho RG. Valores semânticos e discursivos da conjunção aditiva. Scripta. 2001;5(9):219-228.

Charaudeau P. Discurso das mídias. São Paulo: Contexto; 2006.

Charolles M. Un jour (onde day) in narratives. Copenhagen studies in language. 2006;34:11-26.

Cunha GX. O sequenciamento de textos como estratégia discursiva: uma abordagem modular [dissertação]. Belo Horizonte; Universidade Federal de Minas Gerais, Faculdade de Letras; 2008.

Cunha GX. A função de conectores argumentativos no texto da proposta curricular de Minas Gerais. Alfa. 2010;54:203-222.

Cunha GX. A articulação discursiva do gênero artigo de opiniáo à luz de um modelo modular de análise do discurso. Filologia e Linguística Portuguesa. 2012a;14:73-97.

Cunha GX. Uma proposta para o tratamento das relaçôes de discurso temporais no Modelo de Análise Modular do Discurso. Revista do GEL. 2012b;9:29-49.

Cunha GX. A construção da narrativa em reportagens [tese]. Belo Horizonte: Universidade Federal de Minas Gerais, Faculdade de Letras; 2013.

Cunha GX. Para entender o funcionamento do discurso: uma abordagem modular da complexidade discursiva. Curitiba: Appris; 2014.

Cunha GX. Para uma abordagem sócio-histórica da relação entre as noçôes de gênero do discurso e de tipo do discurso. Gragoatá. 2015;20:29-51.

Dahlet V. As (man)obras da pontuação: usos e significações. São Paulo: Humanitas/ Fapesp; 2006.

Duarte RJ. A marcação das relaçôes textuais em textos de gêneros do domínio jornalístico: uma abordagem modular [dissertação]. Belo Horizonte; Universidade Federal de Minas Gerais, Faculdade de Letras; 2008.

Ducrot O et al. Les mots du discours. Paris: Minuit; 1980. 
Fiorin JL. As astúcias da enunciação: as categorias de pessoa, espaço e tempo. São Paulo: Ática; 2010.

Grobet A. La continuité topicale dans des dialogues radiophoniques: quelques relations de discours. Cahiers de linguistique française. 1999;21:101-120.

Guimarães E. Texto e argumentação: um estudo de conjunções do português. São Paulo: Pontes; 2007.

Marinho JHC. O funcionamento discursivo do item "onde": uma abordagem modular [tese]. Belo Horizonte; Universidade Federal de Minas Gerais, Faculdade de Letras; 2002.

Marinho JHC. Uma abordagem modular e interacionista da organização do discurso. Revista da Anpoll. 2004; 16:75-100.

Marinho JHC et al., organizadora. Análise do discurso: ensaios sobre a complexidade discursiva. Belo Horizonte: CEFET-MG; 2007.

Reboul A, Moeschler J. Les connecteurs pragmatiques. In: Reboul A, Moeschler J. Pragmatique du discours: de l'interprétation de l'énoncé à l'interprétation du discours. Paris: Armand Colin; 1998. p. 75-98.

Rossari C. Les opérations de reformulation: analyse du processus et des marques dans une perspective contrastive français-italien. Berne: Lang; 1993.

Rossari C. Les relations de discours avec ou sans connecteurs. Cahiers de linguistique française.1999;21:181-192.

Roulet, E. Complétude interactive et connecteurs reformulatifs. Cahiers de linguistique française, v. 8, p. 111-140, 1987.

Roulet, E. Une approche modulaire de la problematique des relations de discours. In: Mari $\mathrm{H}$ et al. Análise do discurso em perspectivas. Belo Horizonte: FALE/UFMG, 2003, p. 149-178.

Roulet E. The description of text relation markers in the Geneva model of discourse organization. In: Fischer K, org. Approaches to Discourse Particles. Amsterdam: Elsevier; 2006. p. 115-131.

Roulet, E, et al. Un modèle et un instrument d'analyse de l'organisation du discours. 
Berne: Lang; 2001.

Roulet E et al. L’Articulation du discours en français contemporain. Berne: Lang; 1985.

Recebido em: 25/07/2015

Aprovado em: 17/09/2015

Cunha, G.X. Relaçôes de discurso em narrativas jornalísticas... 